45) Overcashier, R. H., D. B. Todd, R. B. Olney : A. I. Ch. E. Journal, 5, 54 (1959)

46) Pyle, O. L., P. L. Rose : Chem. Eng. Sci., 20, 25 (1965)

47) Romero, J. B., L. N. Johanson : Chem. Eng. Progr. Sym posium Series, No.38, 58, 28 (1962)

48) Rowe, P. N. W. M. Stapleton : Trans. Inst. Chem. Engrs., 39. 181 (1961)

49) Rowe, P. N. : Chem. Eng. Progr. Symposium Series, No. 38, 58, 42 (1962)

50) Rowe, P. N., B. A. Partridge: Chem. Eng. Sci., 18, 511 (1963): "Intraction between fluids and particles", p. 135 (London, Inst. Chem. Engrs.), 1963

51) Rowe, P. N. : "Fluidization", p. 15 (1964) (London, Soc. Chem. Ind.)

52) Shen, C. Y., H. F. Johnston : A. I. Ch. E. Journal, I, 349 (1955)

53）白井：“星近の反俯工学”, p.114 (期店) 1959

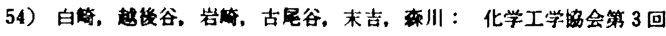



55) Shuster, W. W., P. Kisliak: Chem. Eng. Progr., 48, 451 (1952)

56) Squires, A. M. : Chem. Eng. Progt., 58, [4], 66 (1962)

57) Sutherland, J. P., K. Y. Wong : Can. J. Chem. Eng., 12,
163 (1964)

58) Sutherland, K. S. : Trans. Inst. Chem. Engrs., 39, 188 (1961)

59) 竹田：化学工学, 21, 124 (1957)

60）桐栄，松野，石井，小岛：化学工学協会第 3 回総合シンポシウム



61) van Deemter, J. J. : Chem. Eng. Sci., 13, 143 (1961)

62) Volk, W., C. A. Johnson, H. H. Stotler : Chem. Eng. Progr., 58, [3], 44 (1962)

63) Wilhelm, R. H., M. Kwauk : Chem. Eng. Progr., 44, 201 (1948)

64) Wilhelm, R. H., W. J. Rice : A. I.Ch. E. Journal, 4, 423 (1958)

65）矢木, 宮内：化学工学, 17, 382 (1953)

66）山口：石油学会談, 3. 629,636, 979, 984 (1960), 4, 29 (1961)

67) Yasui, G., L. N. Johansen: A. I. Ch. E. Journal, 4, 445 (1958)

68) Yasui, G., L. N. Johansen : A. I. Ch. E. Journal, 6, 115 (1960)

69) Zenz, F. A., D. F. Othmer: "Fluidization and Fluid. Particle Systems"(Reinhing Publishing Corp., N. Y)., 1960

70) Zwietering. Th. N.: Chem. Eng. Sci., 11, 1 (1959)

III-b. 固 体 反 応*

鞭

\section{1. 流動層無触媒反応の数学的モデル}

れてから，多くの種類の無触媒反応に流動層が応用され ているか，これらの中でも最も普遍的に知られているプ 口七スは硫化鉱の流動パ赎である。鉄鉱石の流動遙元 については, 多くの基砹研究が行なわれているが、結 局，経济的に有利な直接製鉄が実現困難であるとい5理 由から，H-ironプロセス以外にかなりの規模で実用化 されているょうなプロセスは見あたらない。

無触媒反応では，流体ばかりでなく固体粒子自体も反 応により変化するため, 触媒反応の場合とくらへて現象 の理論的取り扱いが複雑になる。このため，流動風によ る固体反応の数学的モデルの研究は少ない現状である。

ここでは，流動層による無触媒反応に関して従来提出 されている数学的モデルについて，新たに展開してみた 理論解析を加味して概説し，さらに，流動冏無触媒反応 の分野で 1960 年以降に発表された主な研究について展 望する，

* 昭和 40 年 7 月13日 受理



この分野で，矢木，国井 ${ }^{311}$ は広範な理論解析を展開 している。すなわち，反応を通じて粒子径が变化しない 場合について，経過時間と粒子内部の反応界面の半径と の間の関係を（1）（4）式で示した。

粒内拡散が律速段階の場合

$$
\begin{aligned}
& \theta / \theta_{0}=1-3\left(r_{c} / R\right)^{2}+2\left(r_{c} / R\right)^{3} \\
& \theta_{0}=R^{2} / 6 D_{s} \alpha\left(c-c^{*}\right)
\end{aligned}
$$

化学反応が律速段階の場合

$$
\begin{aligned}
& \theta / \theta_{0}=1-\left(r_{c} / R\right) \\
& \theta_{0}=R / k \alpha\left(c-c^{*}\right)
\end{aligned}
$$

層内で粒子が反応を完結する時間について

$$
\theta_{\diamond}=\theta_{0} / \Phi \delta
$$

とし， $\Phi$ と $\delta$ とで補正して表わしている。ただし，

$$
\Phi=(\Delta c)_{a v} /\left(c_{0}-c^{*}\right)
$$

であり，ガスが押し出し流れの場合は

$$
\Phi=\left(f_{1} / e\right) /\left\{-\ln \left(1-f_{1} / e\right)\right\}
$$

ガスが完全混合の場合には

$$
\Phi=1-\left(f_{1} / c\right)
$$


としている。さらに， $\phi_{1}=\theta_{b} / \theta_{\mathrm{h}}$ として，末反応率を 粒内挞散律速の場合㤌

$$
1-f_{1}=\frac{1}{5} \phi_{1}-\frac{19}{420}{\phi_{1}}^{2}+\frac{41}{4620} \phi_{1}{ }^{3}-\cdots \cdots
$$

化学反応律速の場合は

$$
1-f_{1}=\frac{1}{4} \phi_{1}-\frac{1}{20} \phi_{1}{ }^{2}+\frac{1}{120} \phi_{1}{ }^{3}-\cdots \cdots
$$

のよラに表わしている（詳細は文献 10）参照)。

矢木，国井 ${ }^{31}$ が求めた（9）（10）式と同様な計算法 で2段，3段の流動層について未反度率を求めてみる と，(11）（14）式のよ5になる。（9）（10）式で右边 の第 3 項以下を省略した式と（11）（14）式に基ついて 四示すると図1がえられ，多段化の効果を知るのに便利 である。ただし， $\phi_{n}=\theta_{b} / n \theta_{n}$

粒内拡散律速の場合

$$
\begin{array}{ll}
2 \text { 段 } & 1-f_{2}=\frac{19}{105} \phi_{2}{ }^{2}-\frac{164}{1155} \phi_{2}{ }^{3} \\
3 \text { 段 } & 1-f_{3}=\frac{369}{1540} \phi_{3}{ }^{3}-\frac{1499}{40040} \phi_{3}{ }^{4}
\end{array}
$$

化学反応律速の場合

2 段 $\quad 1-f_{2}=\frac{1}{5} \phi_{2}{ }^{2}-\frac{2}{15} \phi_{2}{ }^{3}$

3 段 $\quad 1-f_{3}=\frac{9}{40} \phi_{3}{ }^{3}-\frac{81}{280} \phi_{3}{ }^{4}$

これら末反応率の式は，粒子が層内で完全混合の状態 であるとみなして，粒子の排出顆度分布関数を考虑し て誘導された式であるか，層内粒子の反応完結時間を (2),(4) 式で右辺分母の $\left(c-c^{*}\right)$ のかわりに $(\Delta c)_{a_{0}}$ を 採用して表わすことにして，ガスが完全混合の場合以外 は,

$$
(\Delta c)_{a v}=\left(c_{0}-c_{1}\right) / \ln \left\{\left(c_{0}-c^{*}\right) /\left(c_{1}-c^{*}\right)\right\}
$$

て計算することにし，末知量 $c_{1}$ を的媒反応の埸合の数 学的モデルと同様な形のモデルに基ついて算出するとい ら方法る考えられる。ここで，蚛媒反応の場合と同様な 取り报いをしてみよ5。すなかち，ガス反応物か周内で 平均反応率 $f_{1}$ の粒子と接触すると考えると，定常状態 下で均一相モデルの基硴式は，ガス侧の物筫収支から

$$
\frac{d^{2} c}{d z^{2}}-u \frac{d c}{E_{z}}-\frac{1}{d z} E_{z}^{*}=0
$$

とかける。一方，粒子が詹内で完全混合するとして，粒 子儧での物質收支から

$$
f_{1}=f_{0}+\beta u_{0}\left(c_{0}-c_{1}\right) / S
$$

がかける。ところで，反応速度については，

粒内拡散律速の場合には

$$
R^{*}=\frac{\left.3^{\prime} 1-\varepsilon\right) D_{1}}{R^{2}\left\{\left(1-f_{1}\right)^{-1 / 3}-1\right\}}\left(c-c^{*}\right)
$$

化学反応律速の場合には,

$$
\mathrm{A}^{\prime} \mathrm{g}+\mathrm{X}(\mathrm{s}) \stackrel{k}{\stackrel{k^{\prime}}{\rightleftharpoons}} \mathrm{B}(\mathrm{g})+\mathrm{Y}(\mathrm{s})
$$

のような1次の可逆反応を考えると，

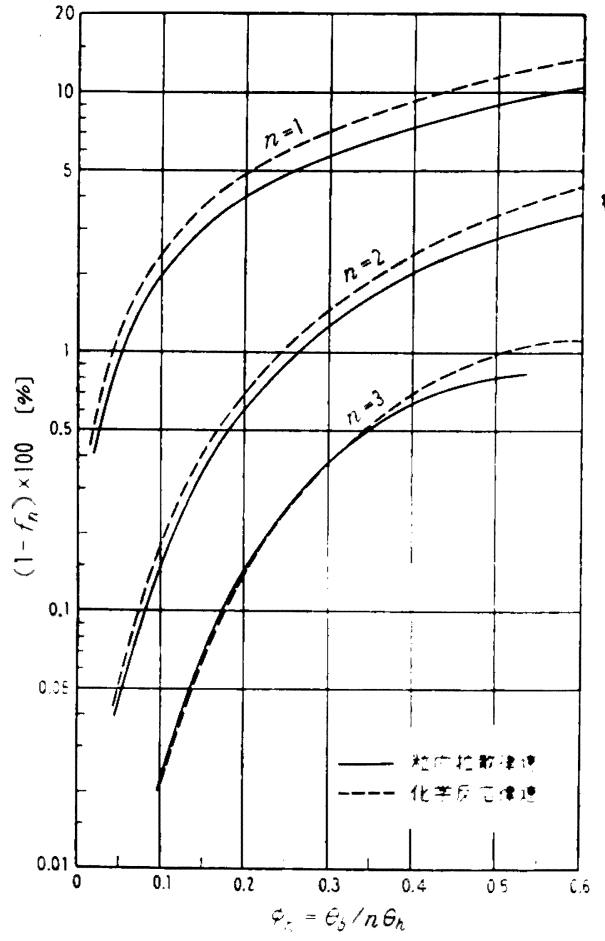

因 1

$$
R^{*}=\frac{3(1-\varepsilon) k\left(1-f_{1}\right)^{2 / 3}}{R}\left(1+\frac{1}{K}\right)\left(c-c^{*}\right)
$$

とかける。粒内拡散律速の場合には（18）式を（16）式 の $R^{*}$ へ代入して，触媒反応の場合と同し境界条件のむ とで解くと層内漫度分布の式が得られるが、さらに, $z=L$, とおいて

$$
\frac{c_{1}-c^{*}}{c_{0}-c^{*}}=\frac{4 a}{(a+1)^{2} \exp \{U(a-1)\}}
$$

がえられる。ただし， $U=u L_{f} / 2 E_{z}$,

$$
a=\sqrt{1+12(1-\varepsilon) E_{z} D_{0} / \varepsilon}\left\{\left(1-f_{1}\right)^{-1 / 3}-1\right\} R^{2} u^{2} \quad(22)
$$

であり，(22）式には $f_{1}$ が含まれているか，（17）式を 代入して $f_{1}$ を消去し，試算法によって（21）式から $c_{1}$ を決定し，（15）式から $(\Delta c)_{a v}$ を求めて $\theta_{b}$ をえ， $\phi_{1}$ を 計算して（9）式から $f_{1}$ が求められる。

層内粒子が完全混合で，化学反応律速の場 合には，

(21）式で $a$ のかわりに $b$ とおいた結果かえられる。

$$
\left.b=\sqrt{1+12(1-\varepsilon) E_{z} k(1+1 /} K\right)\left(1-f_{1}\right)^{2 / 3} / \varepsilon R u^{2}
$$

とくに，ガスが押し出し流れの埸合には

$$
\left.\left(c_{1}-c^{*}\right) /\left(c_{0}-c^{*}\right)=\exp -X^{\prime \prime}\right)
$$

ガスが完全混合の場合には

$$
\left(c_{1}-c^{*}\right) /\left(c_{0}-c^{*}\right)=1 /\left(1+X^{\prime}\right)
$$

となり，粒内払散律速の揚合には

$$
X^{\prime}=3(1-\varepsilon) D_{0} L_{f} / \varepsilon u R^{2}\left\{\left(1-f_{1}\right)^{-1 / 3}-1\right\}
$$


2 相モデルの場合には, 気泡内部に粒子の存在を考え ると両相間での粒子交換についても考虑する必要があ り, 問題がきわわて複雑になるので, ここでは気泡内部 に粒子がない場合について考える。気泡相とエマルショ ン相内のガスがともに押し出し流れとすると

$$
\begin{aligned}
\frac{c_{1}-c^{*}}{c_{0}-c^{*}}=\frac{1}{1+m / h} & \left(\frac{m / h}{\beta_{1}-\beta_{2}}\right)\left\{\frac{\left(m+h+\beta_{1}\right)^{2}}{m+\beta_{1}} \exp \beta_{1}\right. \\
& \left.-\frac{\left(m+h+\beta_{2}\right)^{2}}{m+\beta_{2}} \exp \beta_{2}\right\}
\end{aligned}
$$

たたし， $\beta_{1}, \beta_{2}$ は次の 2 次方程式の根である。

$$
y^{2}+(m+g) y+m(g-h)=0
$$

ここで, $\quad m=F_{\text {er }} / F_{\text {or }}, \quad h=F_{\text {cr }} / F_{\text {er }}, \quad g=\left(F_{\text {er }}+X^{\prime}\right) /$ $F_{\text {er }}$ である。気泡相内ガスは押し出し流れ，エマルショ ン相内ガスは完全混合とい5場合には

$$
\begin{aligned}
& \frac{c_{1}-c^{*}}{c_{0}-c^{*}}=\frac{1}{1+m / h} \\
& \quad\left[e^{-m}+\frac{\left\{h\left(1-e^{-m}\right)+m\right\}^{2}}{h\left\{m(1+g)+h\left(1-m-e^{-m}\right)\right\}}\right]
\end{aligned}
$$

$F_{\mathrm{or}}=F_{\mathrm{o}} / F_{\mathrm{l}}, \quad F_{\mathrm{cr}}=a_{\mathrm{i}} F_{\mathrm{c}} A_{T} L_{s} / F_{\imath}, \quad F_{\mathrm{er}}=F_{\mathrm{a}} / F_{\mathrm{\imath}}$

(24)〜（29）式には $X^{\prime}$ が含まれているので, (21) 式 の圽合と同様に (26),(17) 式と組み合わせて $c_{1}$ がらら れる。

Ketteridge $^{9)}$ は, イルメナイトから粒状ルチルを生産 するプロセスに多段流動層を適用した場合について，装 置から排出される粒子の末反応率を求める目的で理論解 析を報告している。化学反応が律速で，層内で粒子は完 全混合とみなし，反応速度を粒子内反応物の組成の関数 として, 均一系化学反応の場合と同様な形で表わし, 粒 子の排出頻度分布関数と組み合わせて総括的な反応率を 求めている，反応次数は 0 次， 1 次，分数次数の場合に ついて，粒度は均一粒子径の場合と粒度分布を考虑した 場合を取り扱い，各段の大きさがちがう場合についても 解析している，数式展開については開䤄はないか，反応 速度式の表現について夷証が望まれる。反応は

$$
\begin{aligned}
2 \mathrm{FeO} \cdot \mathrm{TiO}_{2}(\mathrm{~s})+1 / 2 \mathrm{O}_{2}=\mathrm{Fe}_{2} \mathrm{O}_{3} \cdot \mathrm{TiO}_{2}(\mathrm{~s})+\mathrm{TiO}_{2}(\mathrm{~s}) \\
\mathrm{Fe}_{2} \mathrm{O}_{3} \cdot \mathrm{TiO}_{2}+\mathrm{TiO}_{2}+3 \mathrm{Cl}_{2} \\
=2 \mathrm{FeCl}_{3}(\mathrm{~g})+3 / 2 \mathrm{O}_{2}+2 \mathrm{TiO}_{2}(\mathrm{~s})
\end{aligned}
$$

で表わされ，酸化と塩素化の 2 段階の高温反応である。 粒子径 $0.211 \sim 0.104 \mathrm{~mm}$ のイルメナイトと空気を約 $1000^{\circ} \mathrm{C}$ で約 $1 \mathrm{hr}$ 酸化し，酸化生成物を塩素ガスと䄪 $1100^{\circ} \mathrm{C}$ で約 $3 \mathrm{hr}$ 反応させて，ガスとルチルとに分離す る。このプロセスはオーストラリヤで開発された16)。粒 子径は反応によって変化しない，ともに反応完結時間か 長い反応たから，多段化の効果が有奻に活用される。

連続式流動層では，層内での粒子混合が著しいため に，粒子とガスとの向流接触操作がえられなかったが， Sutherland ${ }^{26)}$ は逆円錐形のテーパつき流動層装周を開 発して，粗粒単段流和屡で向流操作を実現させた。たた し， $160 \mathrm{~cm}$ 以上の深い居で，しかも流動化開始速度の
1.3 倍以内の低流速域で実現できるということである。

Levey ら ${ }^{11)}$ は, 球形の $\mathrm{UO}_{3}$ 粒子 $(-20+200)$ を水 素還元 $\left(550^{\circ} \mathrm{C}, 1 \mathrm{hr}\right)$ して $\mathrm{UO}_{2}$ とし, さらに弗化水素 化 $\left(204 \sim 315^{\circ} \mathrm{C}\right.$ で $1 \mathrm{hr}$, さらに $315 \sim 704^{\circ} \mathrm{C}$ で $\left.1 \mathrm{hr}\right)$ してUF、にするブロセスに，1/4 のテーパつき流動層 を使用し，流動化開始速度の 1.1 1.2 倍程度の流速で 実験した。邆元，弗化水素化とすに実験範囲内の条件で 粒子反応物に関して近似的に 1 次反応とみなせることを 碓かめ, 流系一次反応の均一相モデルと同形の式で，粒 子の末反応率を粒子に着目して表わした。すなわち,

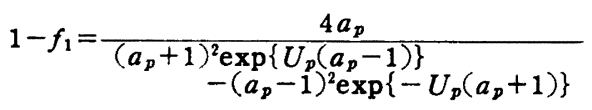

たたし， $U_{p}=u_{s} L_{f} / 2 E_{z p}, a_{p}=\sqrt{1+4 k_{p} E_{z p} / u_{s}^{2}}$ であ $\eta （ 30 ）$ 式中の $L_{f}$ は，流系反応管での物質収支式か ら决定される。

$\mathrm{Rowe}^{23)}$ は, $\mathrm{UO}_{2}$ 粒子を $\mathrm{HF}$ ガスで流動化させて UF、 を生産するプロセスについて，反応速度を

$$
d x / d \theta=-k_{p} x y P
$$

で表わし， $450^{\circ} \mathrm{C} て ゙ ~ k_{p}=5 \times 10^{-4} \mathrm{sec}^{-1} \cdot \mathrm{atm}^{-1}$ と報告し ている，気泡の大きさと上䄯速度から気泡周囲の gas cloud の直径を求め, 気泡の外嗀粒子量を考愿して反応 成瞔を求める計算法を報告している。

藤重”は，磁硫鉄釷の流動ハイ暁の砄究を行ない，単 一粒子について, 反応熱, 対流おょび輻射层熱を考虑し て粒子温度の時間的变化を求め, 粒内抬散律速の場合に 反応界面モデルに基ついて反応速度式を表わした。な お，粒子とガス間の有奻接触効率を考虑すると理論と実 測がよく一致することを示している。さらに，粒子は完 全混合とし, 图内ガスの5ち完全混合と押し出し流れに なるガスの比率を考虑して，ガス反応物の層内濃度分布 を表わす理論式を展開してガス混合の影響をしらへた。 その結果, 転化率の高い埸合に混合の効果が大きくなる とし, 小型流動屏で $L_{f} / D_{T}=2 \sim 4$ 程度の場合, 完全混 合の状態のガスの此率を 0.7 としよい一致をえたこと から，層内流体はかなり完全混合に近いとしている。

\section{2. 無触媒流功居反応の基磁研究}

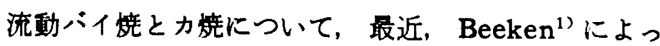
て解説が行なわれた。硫化鉄鉣中に非鉄金属がある量以

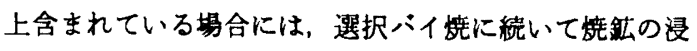
出が行なわれ，残渣は高炉原料として利用される。たと えば，含銅硫化鉄鉱の场合に，硫酸化ハイ焼に䋨いて水 か弱酸で浸出し，さらに，塩索化ハイ焼に続いて漫出し てから高炉へ供給される場合がある（詳細は文献 1) 参 照)。

矢木, 国井 $\left.{ }^{31}\right)$ は、ビロタイトのハイイ焼 $\left(620 \sim 900^{\circ} \mathrm{C}\right)$ 
と閃严鉛鉣のバイ雄 $\left(700 \sim 900^{\circ} \mathrm{C}\right)$ の実験を行ない,こ れら実験条件下で, 前者は化学反応と粒内拡散がともに 影響してくるが，後者は化学反応律速であることを報告 し，理論解析結果に基ついて検討している。

Vanecek 5 ${ }^{30)}$ は，低品位パイライトの流動バイ嬅に ついて熱収支を行ない，熱損失を珹少させる方法につい て考察し、精鉱の添加率とガス中の $\mathrm{SO}_{2}$ 浱度および温 度の関係を示している,

Roggero $^{22)}$ は，莾鉱のZn の浸出率を增加させるため に，亜鉛精鉱の高温流動バイ䇢 $\left(950 \sim 1150^{\circ} \mathrm{C}\right)$ につい て研究し，オーバ・フローとキ+リ・オーバ中の金属成 分の分配と温度との関俰を示している、

流動バイ䇠装置のスケールアッブについて高木7)の 報告がある。流動バイ续の湿式治金への応用について中 島ら ${ }^{15)}$ の研究が行なわれ，硫化鉱中の銅、严鉛の湿式 製鍊のための最適バイ㜣条件を求める方法が発表されて いる,

岡島ら ${ }^{17)}$ は，硫酸焼鉱の選択塩化バイ锛について, 脱銅，脱严鉛，脱琉，鉄の步留りなとにによよはす寸操作条 件の影䈏を明らかにしている，古井ら5)は、ラテライト の選択塩化バイ楛により $\mathrm{Ni}$ を分離する研究を行ない， $\mathrm{Ni}$ 分離率と操作条件の関係を示している，塩化ハイ傎 については，岡元 ${ }^{18)} に よ る$ 総説がある，

鉄釷石の流動僄元については，最近，Brown ${ }^{3)}$ ，およ び Pattison ${ }^{20)}$ によって解説が行圭々れている。海綿鉄 の生産プロセスで, 還元速度は, $950^{\circ} \mathrm{C}$ 以下では $\mathrm{H}_{2}$ ガ スによる方が $\mathrm{CO}$ ガスによる場合よりる高くなる， $\mathrm{H}_{2}$ とCOのいずれでる，へマタイトの嗹元速度の方がマク ネタイトの遙元速度よりるはやくなる，へマタイトを原 料とする直接製鉄で，僄元速度と温度の関俰: $550 \mathrm{C}$ 以下と $750^{\circ} \mathrm{C}$ 以上では，温度上年とともに反応速度が增 加するが， $550 \sim 750^{\circ} \mathrm{C}$ の間で $\mathrm{FeO}$ の生成により迦元速 度か诚殺されて， $550^{\circ} \mathrm{C}$ で逶元速度に極大值が現われる ことをのへている20),

大藏ら ${ }^{19)}$ は，鉄鉱石粒子 $(-28+100)$ を $\mathrm{H}_{2}$ ガスで 流動遙元し、粒内拡散よりも化学反応が遗元過程をより 律速すること，王力の影签は遥元事か 50 60\%で最も 著しいが，高還元率の範囲では影䈏が比較的小さいこと を報告している，なお，流動化開始付近の低流速域で還 元速度が著しく增加する、一マタイトは温度上䄯ととも に還元速度が增加したが， $800^{\circ} \mathrm{C}$ て焼結しはじめ， 850 $\sim 900^{\circ} \mathrm{C}$ で完全に筧結して流動化が停止する。マグネタ イトは還元速度か $600^{\circ} \mathrm{C}$ て最も高くなり, $700^{\circ} \mathrm{C}$ 付近で 生成選元鉄と末僄元物が融合して酸化鉄の周囲汇緻密な 膜が生成し，反応生成物である水蒸気の执散をさまたげ ると述てている,

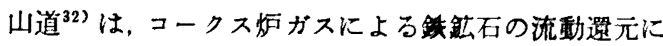
ついて研究し， $\mathrm{Fe}_{2} \mathrm{O}_{3} \rightarrow \mathrm{Fe}_{3} \mathrm{O}_{4} \rightarrow \mathrm{FeO} \rightarrow \mathrm{Fe}$ の各素反応の
反応速度定数を $k_{1}, k_{2}, k_{3}$ として, $k_{1} \gg k_{2}, k_{3}$ であること を示している。なお，総括反応速度定数を各律速過程を 考虑して表わし，流動層内でガスは完全混合とし流体境 膜内の払散を無視して, 還元率の理論解析を行なってい る。さらに，硫酸楛鉱の流動還元プロセスの工業化に関 する研究を行ない，2 段流動層による摆元試験，および パイロットプラントの設計条件について考察し，3段流 動妒が望ましいと結論している，

田中ら ${ }^{28)}$ は電気奶排ガスによる砂鉄の流動還元につ いて実験し，回分式流動層で， $900^{\circ} \mathrm{C}$ では $850^{\circ} \mathrm{C}$ の場 合の約 2 倍の還元速度が得られたことを報告している， 田中ら ${ }^{299}$ は，水性ガスによる砂鉄の流動還元について 実験し，ガス利用率を高くするには多段化にする必要が あることを示している，

Meissner ら ${ }^{13)}$ は，多段流動層により鉄鉱石を $\mathrm{H}_{2}$ や CO ガスで還元するプロセスについて，蒸留の場合の McCabe-Thiele の図式解法と同様な階段作四法を採用 して，段数，逼元率，反応ガス流量間の関係を求める方 法を提案し，小型実験装置でえた実験データを使用して 層効率を考虑した段数計算を行なっている。すなわち， 各段では温度一定で化学平衡が成立するとし， $X \equiv($ 酸

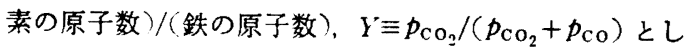
て, 平衡関係: $Y_{n}=f\left(X_{n}\right)$ と酸素収支から之られる操 作線との間で階段作四を行なら方法についてのへててい るささらに，このよ5な四式解法を他のプロセスにも応 用することを試みている，

原子力発電の発展にともなって, 廃冝核然料から金属 ウランを回収するプロセスの開発が研究され，流動層の 応用が行なわれている，Heremans $5^{6)}$ ( $\mathrm{UO}_{2}$ から 六弗化ウランを製造するプロセスについて，回分式流動 層で实験した。関与する反応は

$$
\begin{aligned}
& \text { (酸 化) } 3 \mathrm{UO}_{2}+\mathrm{O}_{2} \longrightarrow \mathrm{U}_{3} \mathrm{O}_{4} \\
& \text { (谴 元) } \mathrm{U}_{3} \mathrm{O}_{8}+2 \mathrm{H}_{2} \longrightarrow 3 \mathrm{UO}_{2}+2 \mathrm{H}_{2} \mathrm{O} \\
& \text { (弗化水絜化) } \mathrm{UO}_{2}+4 \mathrm{HF} \rightleftharpoons \mathrm{UF}_{4}+2 \mathrm{H}_{2} \mathrm{O} \\
& \text { (弗絜 化) } \mathrm{UF}_{4}+\mathrm{F}_{2} \longrightarrow \mathrm{UF}_{6}
\end{aligned}
$$$$
\text { いずれも発熱反応であるが（34），(35）式の反応では }
$$
㠜結をさけるために希积郕として $\mathrm{Al}_{2} \mathrm{O}_{3}$ を 50〜 75\% 添 加するのがよいと述てている，

Scott ら ${ }^{24)}$ は，UF、から UF 6 の製造は，（35）式の ように $\mathrm{F}_{2}$ を使ってできるか，

(酸化) $2 \mathrm{UF}_{1}+\mathrm{O}_{2} \longrightarrow \mathrm{UF}_{6}+\mathrm{UO}_{2} \mathrm{~F}_{2}$

のよ5に $\mathrm{O}_{2}$ を使ってもできることに着目し（36）式の 反応の汪かに、(37!，(34) 式の反応にそれそれ流動風を 応用した。（36）式の反応を1次とみなして反応速度定 数を実験で求めている、

$$
\text { (浐元) } \mathrm{UO}_{2} \mathrm{~F}_{2}+\mathrm{H}_{2} \longrightarrow \mathrm{UO}_{2}+2 \mathrm{HF}
$$

Mecham ら ${ }^{12)}$ は， $\mathrm{UO}_{2}$ ペレットの固定層内の粒子闍 隐に, $\mathrm{MgF}_{2}, \mathrm{CaF}_{2}$, フランダム, $\mathrm{Al}_{2} \mathrm{O}_{3}$ などの粒子( -60 
＋200）を入れて流動弗素化反応を行なった。反応成籍 は固定層たけの場合と同程度だが, 微粉の流動化によっ て温度調節が容易になることを報告している。

石炭の流動酸化と流動乾留については, 最近, Jones ${ }^{7}$ によって解説されている。石炭を部分酸化すると石炭の 性質が変化し, 酸化された石炭を加熱してす粘結性を示 さなくなる。流動乾留を円滑化するための前処理として 流動酸化が行なわれている。石炭は大気中の $\mathrm{O}_{2}$ を吸収 して反応するが，この反応は $250 \sim 400^{\circ} \mathrm{C} て ゙$ 迅速になる ので，このような温度で粉炭を空気で流動化させる。粉 炭を王䈹して煉炭を作るプロセスがあまり成功しなかっ たのは，温度と加熱時間の十分な制御が得られなかった ことに起因したか，この問題が流動層を応用して乾留す ることによって解決されたと述べている7。

Squires ${ }^{25)}$ は，界圧流動層による微粉炭のガス化を水 蒸気と酸素によって行な5プロセスを研究し，

使 用

$a_{6}$ : 両相間での有効比表面䞍

$A_{i}$ ：両相間の界面々積

$A T$ ：愿断面積

$c ：$ カス反応物の湿度

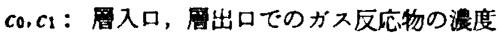

$c^{*}$ ：固相と平衡な気相中の反店物泿度

$(\Delta c)_{a v}$ ：層内での平均有勃漫度推進力

$D$, : 粒内抬散係数

$D_{T}$ ：塔内径

$e$ : 送入ガスと誨的ガスの容稳流量比

$E_{z}$ ：ガスの蚰方向混合拻散俰数

$E_{2 p}$ : 粒子の軸方向混合払散係数

$f_{0}$ ：第一段へ供給される粒子の反纫究

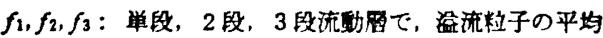
反店率

$\left[\mathrm{cm}^{2} / \mathrm{cm}^{3}(\right.$ bed $\left.)\right]$

$\left[\mathrm{cm}^{2}\right]$

[cm $\left.{ }^{2}\right]$

$\left[\mathrm{mol} / \mathrm{cm}^{3}\right]$

$\left.\mathrm{Jmol} / \mathrm{cm}^{3}\right]$

$\left[\mathrm{mol} / \mathrm{cm}^{3}\right]$

$\left[\mathrm{mol} / \mathrm{cm}^{3}\right]$

$\left[\mathrm{cm}^{2} / \mathrm{sec}\right]$

[cm]

$[-]$

$\left[\mathrm{cm}^{2} / \mathrm{sec}\right]$

$\left[\mathrm{cm}^{2} / \mathrm{sec}\right]$

[-]

$F_{b}$ ：気泡相を流通するガスの容稳流量

$F_{e}$ : 両相間のガス交换速度

$\left[\mathrm{cm}^{3} / \mathrm{sec}\right]$

$F_{e}$ ：エマルジョン相を流通するガスの容積流量

$F_{\mathfrak{l}}$ ：全送入ガスの空積流量

$k$ ：反応速度定数（正反应）

$\boldsymbol{k}^{\prime}$ : 逆反应の反店速度定数

$$
\begin{aligned}
& \mathrm{C}+2 \mathrm{H}_{2}=\mathrm{CH}_{4}, \quad \mathrm{C}+\mathrm{H}_{2} \mathrm{O}=\mathrm{CO}+\mathrm{H}_{2}, \\
& \mathrm{CO}+\mathrm{H}_{2} \mathrm{O}=\mathrm{CO}_{2}+\mathrm{H}_{2}
\end{aligned}
$$

の各反応速度について，回分式および連䋨式流動層によ る実験結果に基ついて広螌な報告を行なっている。

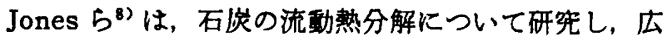
笧囲の温度にわたって，揮発物やタールなどの収率をし らべている。Bowling ら²゙，石炭の炭素化を流動層で 実験した結果, 炭素化速度が增大し, 低温操作が可能に なることを述てている。Pyrcioh ら 211 は，木炭を高圧 下で流動層で水素化して $\mathrm{CH}_{4}$ をえるプロセスについて 研究し，木炭の転化率は高压ほど，また空間速度が小さ いほど高くなることを示している。

最近, 中塩 ${ }^{414}$ は，流動層によって低品位炭を燃焼す る場合の反応速度について報告している。柳井 ${ }^{33}$ (は，褐 炭の流動化反応と活性炭の製造について，さらに，石炭 の流動乾留について報告している。

\section{部 量}

$\begin{array}{rr}k_{p}: 1 \text { 次反応の速度定数 } & {[1 / \mathrm{sec}]} \\ K: \text { 反応の平衡定数 }=k / k^{\prime} & {[-]} \\ L_{f}: \text { 流動層高さ } & {[\mathrm{cm}]} \\ n: \text { 多段流動層の段数 } & {[-]} \\ P: \text { 全 压 } & {[\mathrm{atm}]} \\ r_{\mathrm{c}}: \text { 反応界面までの半径 } & {[\mathrm{cm}]} \\ R: \text { 粒子の半街 } & {[\mathrm{cm}]}\end{array}$

$R^{*}$ ：反店速度

$S$ ：供秴粒子の筫速度

$u$ : ガスの層内平㚬流速

$u_{0}$ ：空塔基靼のガス流速

$u_{s}$ ：固传粒子の速度

$x$ ：粒子内反应物の未反应率

$y$ : ガス反底物のモル分率

[mol(gas) $/ \mathrm{cm}^{3}$ (bed) $\left.\cdot \mathrm{sec}\right]$

$\left[\mathrm{g}(\mathrm{s}) / \mathrm{cm}^{2}\right.$ (bed) $\left.\cdot \mathrm{sec}\right]$

[cm/sec]

$[\mathrm{cm} / \mathrm{sec}]$

$[\mathrm{cm} / \mathrm{sec}]$

$z$ ：周底からの首内高さ

$[-]$

[-]

[cm]

$\boldsymbol{\alpha}$ ：ガス反应物 1 モルと反応子る粒子の容程 [ $\left[\mathrm{cm}^{3} / \mathrm{mol}\right]$

B：ガス反応物 1 モルと反応する粒子の質量 [ $[\mathrm{g} / \mathrm{mol}]$

$\delta$ : 固·気間の有効接触効率

$\varepsilon$ ：屡平妁架间率

$\theta:$ 時 間

$\theta_{0} ：$ 単一料子の反应完結時間

$\theta_{0}$ ：居内粒子の反底完結時間

\section{[-]}

[一]

[sec]

[sec]

[sec]

\section{引用文 献}

1) Beeken, D. W. : Fluidisation, Soc. of Chem. Ind., 62(1964)

2) Bowling, K. Mc. G. and Waters, P. L. : Brit. Chem. Eng., 7, 98 (1962)

3) Brown, D. C. : Chem. Eng. Progr., 59, Symp. Ser. No. 43 53 (1963)

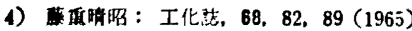

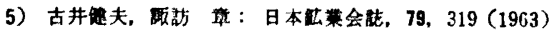

6) Heremans, R. and Schmets, J.: Chem. Eng. Progr., 60, Symp. Ser., No.47, 90 (1964)

7) Jones, D. C. R.: Fluidisation, Soc. of Chem. Ind., 73 (1964)

8) Jones, J. F. and Eddinger, R. T. : Chem. Eng. Progr., 60, 69 (1964)
9) Ketteridge, I. B. : Brit. Chem. Eng., 7, 326, 438 (1962)

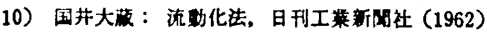

11) Levey, R. P., de la Garza, A. Jacobs, S. C., Heidt, H. M. and Trent, P. E. : Chem. Eng. Progr., 56, 43 (1960)

12) Mecham, W. J., Gabor, J. D. and Jonke, A. A.: Chem. Eng. Progr., 60, Symp. Ser., No.47, 76 (1964)

13) Meissner, H. P. and Schora, F. C.: Trans. Met. Soc. AIME, 218, 12 (1960); 221, 1221 (1961)；224, 160(1962)

14) 中㙁文行：化学工学, 27, 957 (1963)

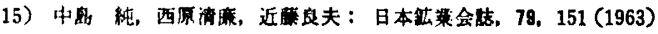

16) Nordin, A. W.: Brit. Chem. Eng., B, 260 (1961); 8, 257 (1963)

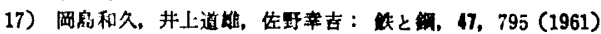




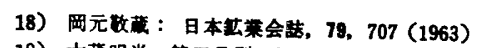

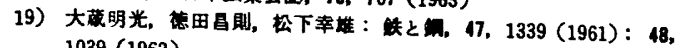
1039 (1962)

20) Pattison, J. R. : Fluidisation, Soc. of Chem. Ind., 84(1964) 21) Pyrcioch, E. J. and Linden, H. R. : Ind. Eng. Chem., 52.
$590(1960)$

22) Roggero, C. E. : Trans. Met. Soc. AIME, 227, 105 (1963)

23) Rowe, P. N.: Chem. Eng. Progr, 80, No.3, 75 (1964)

24) Scott, C. D., Adams, J. B. and Bresee, J. C. : Ind. Eng. Chem., Pracess Design and Develop., 3, 266 (1964)

25) Squires, A. M. : Trans. Instn. Chem. Engrs. (London), 39, 3, 10, 17 (1963)
26) Sutherland, K. S. : Trans. Instn. Ch m. Engrs.(London), 36, 188 (1961)

27）高木需住：化学工学, 26, 654 (1962)

28）田中稳，沓野巷一：铁と，18，1641（1962）

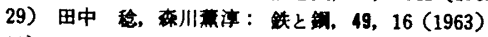

30) Vanecek, V. and Trojan, J. : Brit. Chem. Eng., 8, 556 (1963)

31) Yagi, S. and Kunii, D.: Chem. Eng. Sci., 16, 364, 372 , 380 (1961)

32）山道吉和： 49, 649, 747, 877 (1963)

33）拗井 弘：化学工学, 26, 518, 846 (1962)

\section{III-c. 固液系および固液気系反応*}

\section{1. 粕曹}

気系流動㕌と現象的に類似性のある液采反応形式をあ ザてみると

（i）固液系流動展管内の粒子層が液上年流に上 り流動化された状態で反応が行なわれる場合で，気系に 比へると密度, 粘度, 熱云導度などの差により流動状 況, 云熱, 物質移動も異なり反応工学的特徽も気系の場 合とはまったく違っているよ5に思われる。しかし気系 沉動層の発展に刺激されてか基硌的研究はかなり多い か，工業的応用となると目立つものは少ない。

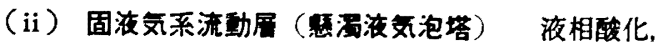
水素添加，重合などにしばしば用いられ，工業的に重要 なすのが多いっ一方，基礎研究については触媒あるいは 化学反応機粹の研究は活発に行なわれているのに比し て, 基碐工学的研究はまた十分でなく，今後に期待され る面が多い。

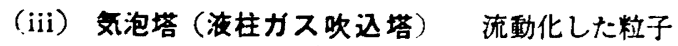
居と本当の液層とでは性格がまったく異なるし，固体か： 介在しないという点で, 工学的にたいら意味が翼なって いるので同一籍畔で扱らことは問題かるしれ奴，共通 点があることも否定できない。この方式も夜相酸化ほか 応用例化重要なるのが見られ, 基磷的研然も最近かなり 進んできている。

本稆では（i）を中心に，補足的に（ii）項にもふれ ながら液系流動層の反応装置への応用について考察して みたい。（iii）項については省略するが，実は(ii) 項に

* 昭和 40 年 8 月 2 日 受理

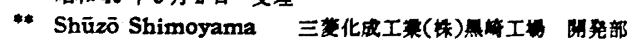

属する反応装置の多くのものは細かい粒子が夜に眯渴 し，その中にガスが吹き込まれるわけで，気泡荅とはと んど同様の方法と考えられる。すちろん液固間の律速過 程を考えると現象はますます複雑となり，気液だけとは 異なるか（ii）項と（iii）項とは関連性の深い方式とい えよ5，



普通流動層といえば固気系を指し，充填層に比して （i）第および物賀移動の向上，（ii）粒子および気体に ついて混合の增加，（iii）固体る連続に流せる。などの 奻果があり，(1) 温度の均一化，(2）能力（対時空间収 率）增加，（3）触媒再生の連続化可能，などの利点があ るので，(イ）逆混合增加による反応率低下，(口）粉化 損失，装圈磨損增加などの欠点を補って余りある効果に より，幾多の重要なプロセスが開柘されてきたことは番 知の通りである。

ところが固液系の場合は流動㬝の効果がそれはど影著 ではない，すなわち充填居です公熱がそれはど覀くない ので温度均一化, 能力向上とい5点で必ずしす流動層に する必要すないし, 均一不均一を問わず液禾反応器とし ては伀統のある拱拌槽式が便利ですあるし，回分，連続 ともに実筑が多いのであえて流動畨を考えなくてすませ るわけである。これまでの実施例をみてす特定の条件に よるすのが多く，一般的な特畏はまだ明らかではない。

固液気系になると灌夜充填塔や摚拌槽に劣らず愁摆液 気泡蒢が多く用いられている。ガス吹迈による港拌奻果 を生かして、擋拌棤における機械的同題あるいは径が大 